\title{
Computational model of human ventilation for electrical stimulation following cervical spinal cord injury
}

\author{
Brian K Hillen*, Ranu Jung \\ From The Twenty Third Annual Computational Neuroscience Meeting: CNS*2014 \\ Québec City, Canada. 26-31 July 2014
}

Towards the development of an implantable stimulator for respiratory pacing, we have developed a computational model of the human ventilatory system to simulate breathing maneuvers. Following cervical spinal cord injury, control of breathing is lost or diminished. If the loss is severe, patients are dependent on mechanical ventilators or electrical stimulators to regain functional breathing. Existing electrical stimulation based respiratory pacing systems typically activate only the diaphragm and cannot adapt to muscle fatigue, changes in respiratory demands, or changes in electrode quality over time. This model will be used to test stimulation controllers that can adapt to such conditions. The model was developed in Simulink/SimMechanics implementing the physiologically realistic muscle model from MSMS $[1,2]$ using published parameters for muscle geometry [3,4]. Diaphragm geometry was modeled as a pulley system in one dimension. Ventilatory compliance was modeled as a damped spring with non-linear stiffness. Integrated phrenic drive was modeled as either a spaced sawtooth (tidal breathing) or a step function (maximal inspiration). The model was able to reproduce tidal breathing and maximal inspiration for uninjured subjects (see Figure 1). When simulating electrical stimulation without fatigue, maximal inspiration was similar but tidal breathing was higher due to the recruitment of larger motor units first. When simulating electrical stimulation as well as fatigue $(50 \%$ reduction in maximal force and a decrease in the power of the fast motor units), tidal breathing was similar to the uninjured case (see Figure 1). Thus, even with fatigue, electrically stimulated muscles are strong enough to produce the submaximal contractions needed for tidal

\footnotetext{
* Correspondence: Brian.Hillen@fiu.edu

Department of Biomedical Engineering, Florida International University,
} Miami, Florida, 33174, USA 
2. Song D, Raphael G, Lan N, Loeb GE: Computationally efficient models of neuromuscular recruitment and mechanics. J Neural Eng 2008, 5:175-184.

3. Gorman RB, McKenzie DK, Pride NB, Tolman JF, Gandevia SC: Diaphragm length during tidal breathing in patients with chronic obstructive pulmonary disease. Am J Respir Crit Care Med 2002, 166:1461-1469.

4. Stubbings AK, Moore AJ, Dusmet M, Goldstraw P, West TG, Polkey MI, Ferenczi MA: Physiological properties of human diaphragm muscle fibres and the effect of chronic obstructive pulmonary disease. J Physiol 2008, $586: 2637-2650$

doi:10.1186/1471-2202-15-S1-P133

Cite this article as: Hillen and Jung: Computational model of human ventilation for electrical stimulation following cervical spinal cord injury. BMC Neuroscience 2014 15(Suppl 1):P133.

\section{Submit your next manuscript to BioMed Central} and take full advantage of:

- Convenient online submission

- Thorough peer review

- No space constraints or color figure charges

- Immediate publication on acceptance

- Inclusion in PubMed, CAS, Scopus and Google Scholar

- Research which is freely available for redistribution

Submit your manuscript at www.biomedcentral.com/submit
C Biomed Central 